\title{
Weekly water-loss from Spherical Water-loss Integrators on a Clearing and below Secondary Growth in Central Amazonia (")
}

\author{
W. L. F. BRINKMANN \\ Instituto Nacional de Pesquisas \\ da Amazônia
}

ABSTRACT :

Spherical ceramic bulbs were set up as weekly water-loss integrators on a clearing and below a 2 year-old Cecropia-community at $\mathrm{Km} 18$ of the Manaus. Itacoatiara Road. The instruments worked well in distinguishing the particular responses of individual sites to the impact of atmospheric agents as sclar radiation, air temperature, air humidity and wind. Water-loss was primarily dependent on the order of magnitude of the weekly total of solar radiation and the presence or lack of a standing crop.

Already a scarce secondary growth will reduce the weekly amount of water lost to the atmosphere considerably. Shelter-wood, however, considering the crop specific demands if introduced to tropical agriculture would provide favourable conditions as far as the impact of atmospheric controls on the tropical environment are concernec.

INTRODUCTION :

The water-loss from spherical porous ceramic is a useful means to estimate the efficiency of integrated environmental controls as solar radiation, air temperature, air humidity. wind, etc. at a particular site. The data obtained, however, do not represent an accurate information on the evaporation and transpiration rates of an individual surface or tissue. But, these data indicate a characteristic response of a specific environment to the impact of its cuntrols. Especially in remote areas away from routine weather stations, the spherical water-loss integrator renders a tentative ecological approach to anunknown environment.

\section{MAterial AND MEthods :}

The spherical water-loss integrators were set up in groups of two at a clearing and under cover of a 2 year-old secondary growth at $\mathrm{Km}$ 18 of the Manaus-Itacoatiara Road (fig. 1).

The spherical bulbs manufactured of pure white clay and burnt at about $800{ }^{\circ} \mathrm{C}$, were set up on the slight slope of a 3 year old clearing about $40 \mathrm{~cm}$ above the ground. While bulb 1 and bulb 2 were fully exposed to the atmospheric agents on the uncovered white sands, bulb 3 and bulb 4 were protected by a dense cover of Cecropia-communities (Brinkmann and Góes Ribeiro, 1971). Bulb 2 and bulb 4 were exposed at mid-slope, while bulb 1 and bulb 3 were set up at hill-top. The soils of the experimental site were poor white sands, typical for slash and burn agriculture experiments along the

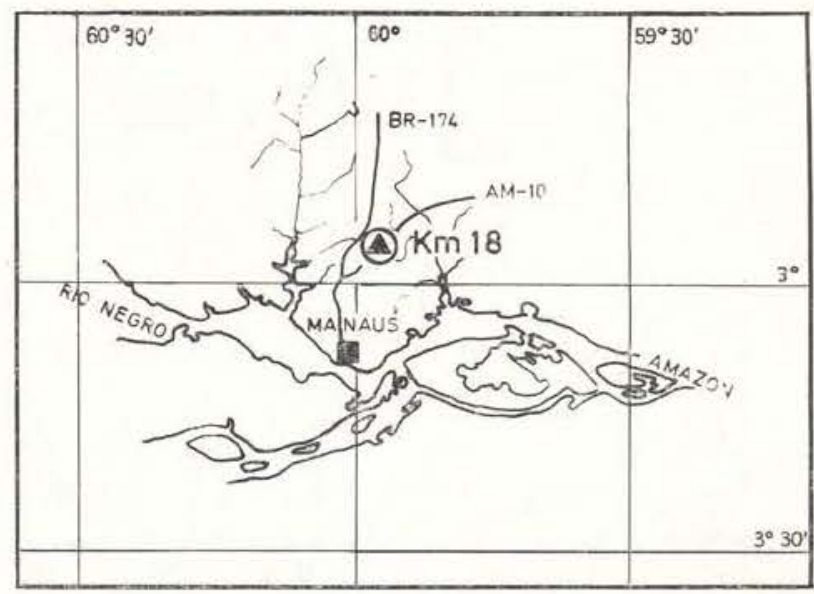

FIGURE 1 - Experimental site for water-loss evaluations in Central Amazonia.

(*) - Forestry Research Program, INPA. This Program is supported by the Conselho Nacional de Pesquisas and the Banco Nacional de Desenvolvimento Econômico (FUNTEC). 
Road AM-10. The cleared plots are used for the growing of maniok and pineapples but have to be abandoned after a couple of years as available plant nutrients are leached and crops suffer from serious nutrient deficiency. These particular soils were described by IPEAN (1969).

The spherical water-loss integrators (volume about $1200 \mathrm{ml}$ ) were refilled with destilled water in weekly intervals. To avoid the development and spreading of colonies of fungi and bacteria in the pore-system of the bulbs, the water was blended with a strong fungicide. The surface of the bulbs, however, was brushed thoroughly every week before resetting of the instruments.

Although the ceramic bulbs did not have Exactly the same size and volume, a laboratory test proved the fact, that water-loss over a prefixed period of hours was nearly the same for all bulbs involved. The experiment was undertaken under controlled conditions for air temperature, air humidity and wind. Under field conditions, however, water-loss was affected by the instantanuously available water content and pressure in the bulbs exposed to the impact of solar radiation, i.e. water-loss was not the same, when the bulbs were exposed to an equivalent impact of atmospheric controls in the beginning or in the end of the weekly period of measurements.

Therefore, the identification of a varied environment was subject to water-loss measurements in volume \%. week ${ }^{-1}$. As evaporation is widely controlled by solar radiation, the water-loss of the spherical ceramic bulbs was related to the weekly total of solar radiation (cal. $\mathrm{cm}^{-2}$. week ${ }^{-1}$ ) incident on the spherical surface of a Bellani radiation integrator (fig. 2).

\section{RESULTS AND DISCUSSION :}

The spherical water-loss integrators recorded characteristic variations among each other as far as exposure to solar radiation was concerned. Away from the two significantly distinguished exposure types, i.e. the two groups

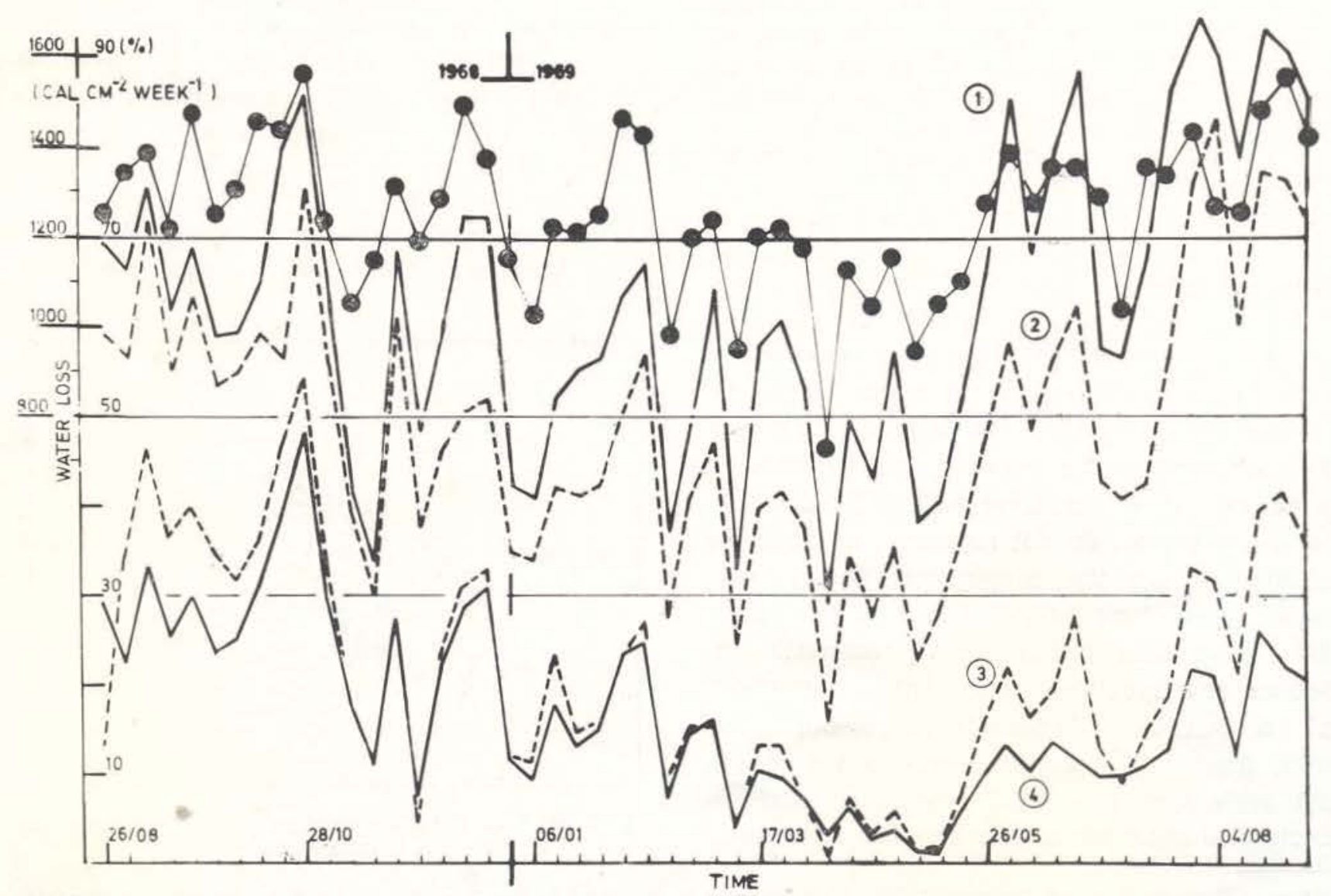

FIGURE 1 - Weekly totals of incident solar radiation (cal. $\mathrm{cm}^{-2}$. week-1) and weekly water-loss (volume \% , week-1) of 4 water-loss integrators (spherical ceramic bulbs) set up on a clearing and under cover of a Cecropia-community. 
of ceramic bulbs set up at the clearing and under cover of young secondary growth, small variations inbetween each group were observed. These variations, however, were due to local individuality in the response to atmospheric agents. During the period of measurements (August 26th, 1968 to September 1st, 1969) the graphs of solar radiation (cal. $\mathrm{cm}^{-2}$. week- ${ }^{-1}$ ) and water-loss (volume $\%$, week ${ }^{-1}$ ) were identical in outline, although different in their order of magnitude (fig. 2). High dry season rates of recorded weekly totals of solar radiation and water-loss (August 26th, 1968 to November 4th, 1968 and June 2nd, 1969 to September 1st, 1969) were interupted by considerably lower wet season values (No. vember 11th, 1968 to May 26th, 1969J. Peaks and lows of all 5 graphs were recorded coinci. dently an obvious signal for a close correlation of the weekly total of solar radiation and the accumulative weekly water-loss. The presence of vegetation or the exposure of the buibs on a clearing determined the amount of water lost to the atmosphere, but did not affect the seasonal distribution of the observed data (fig. 2) .

The spherical ceramic bulbs set up on the clearing (bulb 1 and bulb 2) rendered the exspected departure in weekly water-loss at the top of the hill and at mid-slope, mainly in consequence of variations in the duration of daily solar radiation. The incident solar radi. ation lasted at about 40 to 50 minutes a day longer at the hill-top, prevailing in the late afternoon. This had a considerable effect 0 . the water-loss of the bulbs, because of longer the lasting maximum impact of integratec: atmospheric agents on bulb 1 (tab. 1, fig. 2) .

Obviously e similar relationship was observed for the couple of water-loss integrators set up below a 2 year-old Cecropia-community. The calculation of the ratios bulb $1 /$ bulb 2 and bulb $3 /$ bulb 4 based on the average weekly water-loss $(\%)$ over the period of measurements redered 1.2 and 1.3 , respectively, i.e. the departure of the water-loss according to exposure occured simultanuously and was not controlled by the vegetation cover present at the experimental site.

The water-loss of the spherical ceramic bulbs exposed to full impact of atmospheric agents (bulb 1 and bulb 2) was considerably higher than that of those bulbs (bulb 3 and bulb 4) partly protected by the cover of a 2 year-old secondary growth (tab. 1, fig. 2).

The spherical water-loss integrators set up below the secondary growth were exposed to only a fraction of the weekly total of incident solar radiation. Although the shade-effect on the bulbs was heavy, the about $3 \mathrm{~m}$ high Cecropia-community allowed the penetration of solar radiation through the canopy for at least some hours a day dependent on the angle of incidence and overcast. An important factor in controlling the water-loss of the ceramic bulbs was the vapor pressure deficit in the near soil surface atmosphere. Relative air humidity at the experimental site was always at $100 \%$ at night, independent of exposure. But, during daytime the vapor pressure deficit was de. pendent mainly on direct solar radiation, i.e. with sun behind clouds, air humidity increased rapidiy below the secondary growth, likewis:, but less pronounced at the clearing. After rainfall, however, air humidity decreased rapidly at the clearing exposed to direct solar radiation, while it decreased only with a great time delay below the Cecropia-community. Both events contribute considerably to the significantly great departure in water-loss of clearing exposed and secondary growth protected ceramic bulbs (fig. 2) .

At the experimental site the distance between water-loss integrators set up on the clearing and those below the cover of the secondary growth was less than 30 meters. Collected data (tab. 1, fig. 2) point out, that significant variations in water-loss occured at verk short distances, rendered by different solar radiation efficiency, obviously moderated by the standing crop.

\section{CONCLUSIONS :}

The obtained water-loss data from the spherical ceramic bulbs exposed on the clearing and below a 2 year-old Cecropiacommunity at the experimental site are striking evidence of the usefulness of the set up instruments with regard to an evaluation of the impact of atmospheric agents on the tropical environment. The sensitivity of the 
water-loss integrators was sufficiently high to distinguish already small differences in ex. posure and vegetation cover over very short distances, when measured in weekly intervais. The spherical ceramic bulbs are a means that enables a tentative approach to sites where routine weather observations are lacking and the setting up of sophisticated microclimatic facilities is too expensive to be undertaken. The water-loss integrators, however, are not suitable for hourly or daily records because of their inefficiency to achieve short period responses to weather. The spherical ceramic bulb method fails in the measurement of plant responses to the action of environmental controls, but supplies favourable informations as far as the impact of atmospheric agents on small ecological units is concerned. The water-loss integrators open at least a route, to measure the response of the natural or man-made tropical environment to climatic quantities in time and space. Obtained data also prove the fact, that a pre-determined shelter-wood system, evaluated for every particular crop, will provide tropical agriculture with a considerable benefit as far as the impact of environmental controls as solar radiation, air humidity, air temperature and wind on crops is concerned.

\section{RESUMO}

Bulbos esféricos de ceramica foram instalados numa clareira, sob uma comunidade de Cecrupia de dois anos, no $\mathrm{Km} 18$ da Estrada Manaus-Itacoatiara.

Os instrumentos funcionaram satisfatoriamente como integradores da perda semanal de água permitindo distinguir as respostas de sitios individualizados ao impacto de agentes atmosféricos como a radiação solar, temperatura do ar, umidade do ar e ventos.

A perda d'água dependeu primariamente da ordem de grandeza da radiaçāo solar total durante a semana e àa presença ou ausencia de vegetação.

Um raio crescimento secundário já é suficiente para reduzir consideravelmente a perda semanal de água. Árvores de sombra, consideradas as exigên. cias especificas, se introduzidas na agricultura tropical, poderiam proporcionar condiçōes favoráveis para o controle do impacto dos fatores atmosféricos.

\section{LITERATURE CITED :}

Brinkmann, W. L. F. and M. N. Góes Ribeiro

1971 - Air temperatures in Central Amazonia. II - The effect of near-surface temperatures on land-use in the Tertiary region of Central Amazonia. Acta Amazonica 1(3): 27-32

I P E A N

1969 - Os solos da área Manaus-Itacoatiara. Estudos e Ensaios. № 1, 117 p.

\begin{tabular}{|c|c|c|c|c|c|c|}
\hline & \multicolumn{2}{|c|}{ hill - top } & \multirow[b]{2}{*}{ ratio } & \multicolumn{2}{|r|}{ mid-slope } & \multirow[b]{2}{*}{ ratio } \\
\hline & clearing & below cover & & clearing & below cover & \\
\hline & bulb 1 & bub 3 & bulb 1 /bulb 3 & bulb 2 & bulb 4 & bulb 2 /bulb 4 \\
\hline dry season & $76 \%$ & $27 \%$ & 2.9 & $61 \%$ & $21 \%$ & 2.9 \\
\hline rain season & $49 \%$ & $13 \%$ & 3.8 & $38 \%$ & $11 \%$ & 3.5 \\
\hline period & $61 \%$ & $20 \%$ & 3.1 & $49 \%$ & $15 \%$ & 3.3 \\
\hline
\end{tabular}

TABLE 1 - Average water-loss (volume \%) of spherical ceramic bulbs set up on a clearing and below secondary growth at $\mathrm{Km} 18$ of the Manaus-Itacoatiara Road (AM-10). 